\title{
Research on Service-Oriented International Trade Information Management System
}

\author{
Dejun $\mathrm{Yu}^{1}$ and Feilin $\mathrm{Luo}^{2}$ \\ ${ }^{1}$ Associate professor, Dianchi College of Yunnan University \\ ${ }^{2}$ Lecture, Dianchi College of Yunnan University
}

Keywords: International trade; Information management; Information technology; Service oriented

\begin{abstract}
With the rapid economic development, the old management mode has seriously restricted the quality and efficiency of international trade. It is quite necessary to replace the traditional management methods with information management approaches. Starting from the stages of China's foreign trade development, this paper explores the general process of international trade business, analyzes the problems existing in the development of international trade business and proposes the framework of service-oriented international trade information management system.
\end{abstract}

\section{Introduction}

The rapid development of information technology has promoted the transformation of business operation mode. As the main body of the international trade activities, international trade enterprises definitely should innovate the business operation mode based on advanced information technology. The application of service-oriented international trade information management system shows obvious advantages in establishing a risk control system, reducing the cost of manufacturing, logistics and customs clearance, as well as improving the efficiency of customs clearance.

\section{Current State of International Trade Development and Information Management}

Stages of Foreign Trade Development. Since China's accession to WTO, the continuous increased technology exports have brought considerable economic benefits. In 2015, China's exports of hightech products reached 3661.289 billion yuan [1], almost 20 times the exports in ten years ago, 5 times more than that of five years ago. In recent years, the export of high-tech products has been occupying $30 \%$ of the total amount of foreign trade in China. The operation mode of China's foreign trade enterprises can be divided into three stages:

1. Blindly advocating stage: Long before China's accession to WTO, the foreign trade has already begun and the occurrence rate of international trade disputes before 2002 is less than that in recent years. The reason is at that time most enterprises involved in global trade are domestic wellknown large and medium-sized enterprises. After joining WTO, more and more small and mediumsized enterprises without a primitive capital accumulation join the global trade, therefore causes a lot of disputes.

2. Reasonably follow suit stage: since 2002 to 2008, with the state-owned large and mediumsized enterprises closing down or making transformation, many talents have joined the small and medium enterprises, leading to the rapid development of these private enterprises. They no longer blindly worship foreign buyers and begin to learn from each other, resulting in the formation of foreign trade frontier area such as Jiangsu and Zhejiang, Guangdong and Beijing.

3. Carefully selected stage: The intensifying reform causes a surge in the number of producers in China. As more foreign manufacturers open factories in China, the already fierce competition in production industry becomes increasingly white hot.

Research Status of International Trade Information Management. International trade management system [2] comprehensively applies the function of requisition purchase, order, supplier management, price management, effectively bilateral controlling and tracking the whole process of procurement logistics and capital flow, improving the information management of material supply. Office automation can simplify the operation for the company's operating 
personnel, meanwhile, the leaders can simultaneously make decisions and give feedbacks. All the most concerned information such as the latest market trends, the potential customers, competitors and cooperative partners can be found on the internet; in addition, relevant enterprise information such as the business performance, business scope can also be accessed by other enterprises through Internet.

\section{International Trade Enterprise Business Investigation and Problem Analysis}

International Trade Enterprise Business Investigation. International trade import and export enterprises [3] mainly take the international trade, international bidding agent, project bidding and government procurement tenders as their main business. They are in charge of the introduction of patented technology; undertaking the import and export business of complete sets of equipment, machinery, electronics, etc.; undertaking the international bidding for the procurement, government procurement; agenting the importation of dangerous chemicals; operating consignment, barter and entrepot trade.

Table 1 The general procedures of goods import and export in international trade

\begin{tabular}{|c|c|c|}
\hline No. & Procedures & Explanation \\
\hline 1 & Offer & $\begin{array}{l}\text { For those taking inquiry and quotation as the beginning of the trade, } \\
\text { commonly used quotations are: FOB, CNF, CIF, etc. }\end{array}$ \\
\hline 2 & Order & $\begin{array}{l}\text { If both sides accept the quotation, then they need to sign the "purchase } \\
\text { contract". }\end{array}$ \\
\hline 3 & $\begin{array}{l}\text { Preparing } \\
\text { Goods }\end{array}$ & $\begin{array}{l}\text { The quality and specifications of the goods in stock shall be verified } \\
\text { according to the requirements of the contract. }\end{array}$ \\
\hline 4 & Packaging & Different forms of packaging should be used for different goods. \\
\hline 5 & $\begin{array}{l}\text { Customs } \\
\text { Clearance }\end{array}$ & $\begin{array}{l}\text { The customs formalities for import and export commodity inspection } \\
\text { mainly include quarantine inspection, sampling, inspection and } \\
\text { certification }\end{array}$ \\
\hline 6 & Shipment & $\begin{array}{l}\text { Having the goods insured and choosing to use full container or tank } \\
\text { container according to the "purchase contract". }\end{array}$ \\
\hline 7 & $\begin{array}{l}\text { Transportation } \\
\text { insurance }\end{array}$ & $\begin{array}{l}\text { Transportation insurance is usually negotiated by the two sides in the } \\
\text { signed "purchase contract". }\end{array}$ \\
\hline 8 & $\begin{array}{l}\text { Bill of lading } \\
(\mathrm{B} / \mathrm{L})\end{array}$ & $\begin{array}{l}\text { Bill of lading }(\mathrm{B} / \mathrm{L}) \text { is a document issued by the carrier for guaranteeing } \\
\text { the exporters receive payment and importers receive merchandise. }\end{array}$ \\
\hline 9 & $\begin{array}{l}\text { Exchange } \\
\text { settlement }\end{array}$ & $\begin{array}{l}\text { All kinds of documents shall be prepared and presented within the } \\
\text { validity of the } \mathrm{L} / \mathrm{C} \text { to the bank for settlement. }\end{array}$ \\
\hline
\end{tabular}

Problems in the Development of International Trade. Service trade lags behind: The scale of service trade is rather small and the undeveloped service industry restricts the development of service trade. Besides, the structure of service trade is not reasonable, including the irrational structure of export sector, the imbalanced regional development of service trade, the imperfect laws and regulations of service trade as well as the backward service management system.

Technical trade barriers seriously impede the export of the goods in China: In China, more than $60 \%$ of the export enterprises suffered from foreign technical barriers to trade, and the goods suffered foreign technical barriers accounts for more than $25 \%$, which is about 45 billion to 50 billion USD [4]. As the most challenging non-tariff barrier facing by China's foreign trade enterprises, technical barriers to trade has seriously affected the export of goods in China, increasing the cost of trade.

International trade friction upgrades, foreign trade risks increase: Recently, the increasing trade friction has hindered the development of China's foreign trade. Many countries have lodged antidumping lawsuits against Chinese products, especially since 1990s, causing serious economic losses and leaving an adversely impact.

Some serious problems exist in the financing of international trade, including the undiversified financing approach, the uneven distribution of funds among banks with different nature, the 
frequent legal disputes of international trade financing.

\section{Service-Oriented International Trade Information Management}

The Framework of Service-Oriented International Trade Information Management. In view of the problems existing in the development of international trade, this paper puts forward the service-oriented international trade information management system based on information technology. Fig. 1 shows the framework of the service-oriented international trade information management system.

According to the characteristics of international trade, trade management system can be divided into 9 subsystems [5]. The sub-module for each subsystem basically reflects the overall control of the relevant business in the course of export and import operations, entrepot business and domestic trade business.

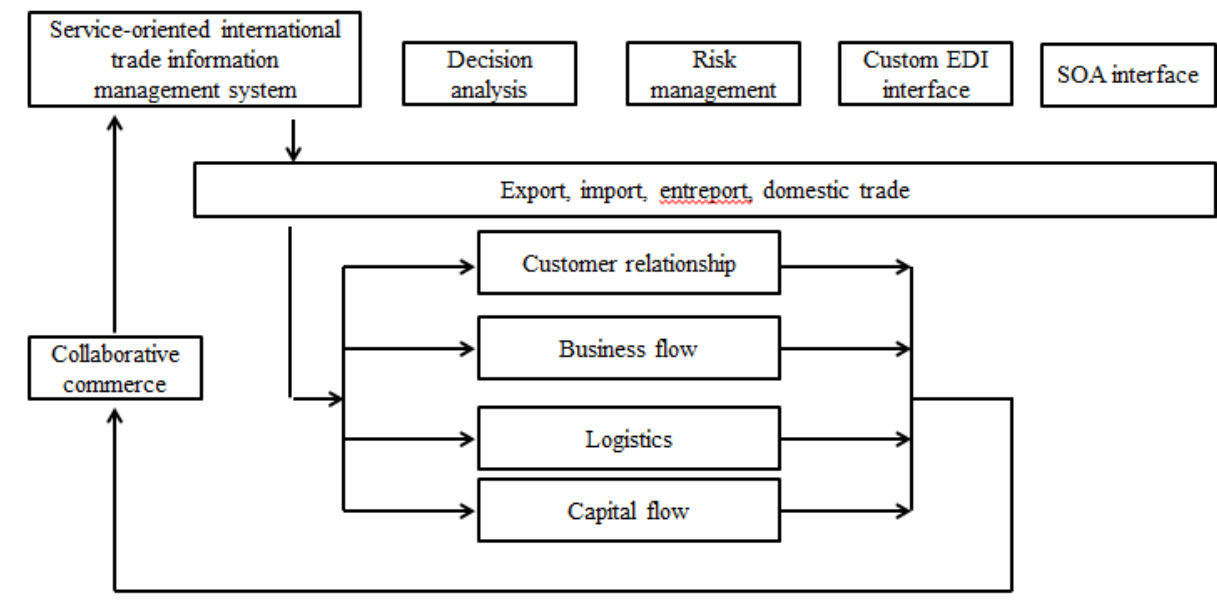

Figure 1. Service-Oriented International Trade Information Management Framework

Service-oriented information management system can improve the trade information management of trade, sales and inventory, and consolidate the industry chain. Besides, this system can be conveniently used by domestic and foreign trade personnel, enables the leader keep up with the execution of the contract, the stock and the logistics in order to analyze the current status and make future decisions, reducing management risk and improving operational efficiency.

The Objectives of Information Technology. This paper presents an innovative service-oriented information management system with the following objectives [6].

Establishing the international trade business information management system, enabling the enterprises quickly realize the transformation of business strategy. Accelerating the information exchange with customers and suppliers in goods export business; keeping abreast of the information about inventory, sale and storage at various distribution locations in import business.

Establishing a risk supervision system for international trade. Combing the resource management of corporate customers and goods to establish a complete customer information evaluation and risk prevention system; setting up an examination and approval system and controlling the risk in the transaction process.

Managing capital flow and controlling cost. The system provides a cost management mechanism for ex ante budget calculation, cost management and post settlement. Through combing business flow, logistics and capital flow, it can provide basic data and analysis for a higher level of information system.

Decision support functions. The management system can dynamically reflect the various elements such as sales, costs, profits, etc., timely and accurately grasp the overall status of the company, provide the required information, data support to the leader, and offer the implementation feedback to the decision-makers. 
Open system architecture. It complies with SOA specification and provides access to other enterprises interface. Through EDI interface, it has access to the management department and the public information provided by customs. Thereby, a complete supply chain system can be formed by electronic means.

Global 24-hour business support requires access to the company's system at any time and access to business processing, in order to quickly respond to the global business demands.

\section{Summary}

Under the pressure of global competition, it is essential for enterprises to establish a serviceoriented international trade information management system, making more efficient use of resources, reduce costs and enhance competitiveness.

\section{References}

[1] Li Y, Xiong L. Information Services Platform of International Trade Based on E-commerce[C]// 2010 International Digital Trade and Mobile Commerce Seminar. 2010.

[2] Wei L. Construction of E-commerce Information Services Platform in International Trade [J]. Advanced Materials Research, 2014, 926-930: 2512-2515.

[3] Bao Ying, Wang Qinqin, Chen Hao et al. On the Information Management of Internet Commerce and International Trade [J] Comprehensive Digest, 2015 (9): 91-91.

[4] Zhang Baoming. E-commerce Operational Management [M]. Beijing: Tsinghua University Press, 2014. 